\title{
Large-Scale Mode Impacts on the Sea Level over the Red Sea and Gulf of Aden
}

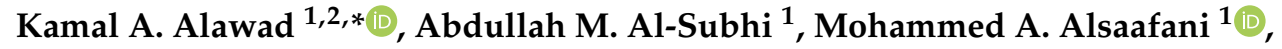 \\ Turki M. Alraddadi ${ }^{1}$, Monica Ionita ${ }^{3,4}$ and Gerrit Lohmann ${ }^{3,4}$ (C) \\ 1 Marine Physics Department, Faculty of Marine Sciences, King Abdulaziz University, Jeddah 21589, Saudi \\ Arabia; amalsubhi@kau.edu.sa (A.M.A.); malsaafani@kau.edu.sa (M.A.A.); talraddadi@kau.edu.sa (T.M.A.) \\ 2 Weather Forecast division, Sudan Meteorological Authority, Khartoum 574, Sudan \\ 3 Paleoclimate Dynamics Group, Alfred Wegener Institute Helmholtz Center for Polar and Marine Research, \\ Am Handelshafen 12, 27570 Bremerhaven, Germany; Monica.Ionita@awi.de (M.I.); \\ Gerrit.Lohmann@awi.de (G.L.) \\ 4 MARUM-Center for Marine Environmental Sciences, University of Bremen, 330440 Bremen, Germany \\ * Correspondence: kmohamad0001@stu.kau.edu.sa
}

Received: 6 August 2019; Accepted: 18 September 2019; Published: 24 September 2019

\begin{abstract}
Falling between seasonal cycle variability and the impact of local drivers, the sea level in the Red Sea and Gulf of Aden has been given less consideration, especially with large-scale modes. With multiple decades of satellite altimetry observations combined with good spatial resolution, the time has come for diagnosis of the impact of large-scale modes on the sea level in those important semi-enclosed basins. While the annual cycle of sea level appeared as a dominant cycle using spectral analysis, the semi-annual one was also found, although much weaker. The first empirical orthogonal function mode explained, on average, about $65 \%$ of the total variance throughout the seasons, while their principal components clearly captured the strong La Niña event (1999-2001) in all seasons. The sea level showed a strong positive relation with positive phase El Niño Southern Oscillation in all seasons and a strong negative relation with East Atlantic/West Russia during winter and spring over the study period (1993-2017). We show that the unusually stronger easterly winds that are displaced north of the equator generate an upwelling area near the Sumatra coast and they drive both warm surface and deep-water masses toward the West Indian Ocean and Arabian Sea, rising sea level over the Red Sea and Gulf of Aden. This process could explain the increase of sea level in the basin during the positive phase of El Niño Southern Oscillation events.
\end{abstract}

Keywords: sea level anomaly; large-scale mode; El Niño Southern Oscillation; East Atlantic/West Russia; Empirical Orthogonal Function; Red Sea and Gulf of Aden

\section{Introduction}

Oceanic and atmospheric teleconnection through large-scale modes is the most striking phenomenon that is associated with recent global warming. From the second part of the 20th century, there has been strong observational evidence that global warming causes the global mean sea level to rise, with concern that the rise rate will accelerate with time through the end of the 21st century, threatening coastal populations [1,2]. Thermal expansion of the water and melting of land-locked ice are the major contributors of this rise [3,4]. However, the regional sea level can differ in the trend and pattern of variability from those of global means, due to, for example, local surface winds, ocean currents and spatial variations in salinity, ocean heat uptake, and the Earth's gravity field $[3,5]$. Thus, investigating the sea-level variability in some regions, as well as the prediction of the future scenario of sea level rise, requires understanding the different driving factors for those regions $[6,7]$. 
In general, the main reasons for sea level variations are the geological (i.e., changes of seafloor shape by tectonic plates movements), regional drivers (i.e., inverse barometric effect, wind and wave set-up, steric effect, and etc.) and the large-scale drivers (i.e., large-scale oceanic and atmospheric circulations) [8]. Globally, sea level climatology is prominently modulated by the large-scale modes in the global oceans [9-15]. At the same time, in semi-enclosed basins, sea level variability has strong links with the global climate that governs the long-term spatial pattern and temporal variability in trends [16-20].

In the Red Sea (RS), a number of studies have been carried out on the controlling factors of the sea level, but mainly from the local view and looking for seasonal variability while using short-term data. These results agree that the local surface wind and the combined effect of evaporations and water exchange with the Gulf of Aden (GA) govern sea level variability [21-25]. However, the sea level increases in winter and decreases in summer. While this is true, there are no long-term studies on this topic that are associated with physical mechanisms so far, primarily because of the non-availability of long-term in situ data combined with a poor coverage. For that reason, few studies have used reanalysis data to investigate this relation [26,27]; nevertheless, the responsible physical mechanisms are still unclear and not yet explored. In addition, other studies used proxy data that were constructed from paleoclimate sources [28-31]. Felis et al. (2000) [32] used 245 years data of coral oxygen isotopes from the Ras Umm Sidd Northern RS and investigated the signal of El Niño Southern Oscillation (ENSO), North Atlantic oscillation (NAO), and North Pacific teleconnection. They speculate that these modes consistently contribute to climate variability, where the cold NAO period increases the aridity conditions in the Northern RS, while the warm period decreases it. Another study found good positive correlation between Arctic oscillation (AO) and atmospheric pressure in the Northern RS concurrent with sea surface temperature (SST) decreasing in the entire RS as well as Eastern Mediterranean and the Black Sea during the positive phase [33]. That is due to the advection of cold and dry air masses from the North Pole. Furthermore, Monica et al. (2014) [34] used coral oxygen isotopes from the Southern RS during the winter season. They indicated that the temperature and salinity variations from 1930 to 1960 are mainly affected by ENSO, while there is evidence of change that the variability from 1960 to 1990 is related to the ENSO-independent part of the East Asian Winter Monsoon (EAWM).

On other hand, Papadopoulos et al. (2013) [35] and Abualnaja et al. (2015) [36] linked the extreme air-sea heat exchange with climate modes. They found that, during the winter season, the NAO was active in the northern part, the East Atlantic/West Russia (EAWR) pattern more in the central, and the Indian Monsoon Index (IMI) in the southern, while the multivariate El Niño index (MEI) is more active in the south during the summer season.

It is clear that only a few studies link the RS and GA with large-scale modes. Motivated by the above findings [26-36], we speculate that climate variability has significant impact on sea level variability in the RS and GA, with seasonal and interannual fluctuations that can be correlated with large-scale climate modes. Taking this in consideration, the purpose of this effort was to fill this gap while using archiving, validation, and interpretation of satellite oceanographic (AVISO) sea level anomaly (SLA) data. In this study, we show (1) which signals of the SLA are dominant, (2) the dominant modes and pattern of variability, and (3) the possible physical mechanism with ENSO and EAWR.

The paper is structured, as follows: Section 2 describes the features of the study area with the used data sets. Section 3 presents the results that include three steps: (i) the dominant patterns of SLA are identified through the Empirical Orthogonal Function (EOF) analysis; (ii) the linkage with large-scale modes; and, (iii) the possible physical mechanism is inferred through regression and correlation maps. These results are discussed in Section 4, and Section 5 summarizes the main conclusions.

\section{Data and Methods}

\subsection{Study Area}

The RS and GA (Figure 1) are the extensions of the Indian Ocean (IO) in the northwestern part that connects through the Arabian Sea (AS). The RS water is very saline and dense due to a high 
evaporation rate, lack of precipitations, and fresh water input. The wind pattern follows the high land plateau on both sides. During the winter season, the wind converges in the center near $18^{\circ} \mathrm{N}$; the northwesterly winds govern north of the convergence zone, while the southeasterly wind in the south $[21,37]$. During the summer season, the northwesterly wind is prominent in the entire area.

When compared to the RS, the GA water is fresh due to open exchange with the AS, with salinity fluctuates around $36 \mathrm{psu}$. The surface wind in the GA is strong westerly during the summer season, while it is weak northeasterly during the winter season [38]. The eastern geographic limits of GA extend to Cape Guardafui-Somalia $\left(51.2^{\circ} \mathrm{E}\right)$.

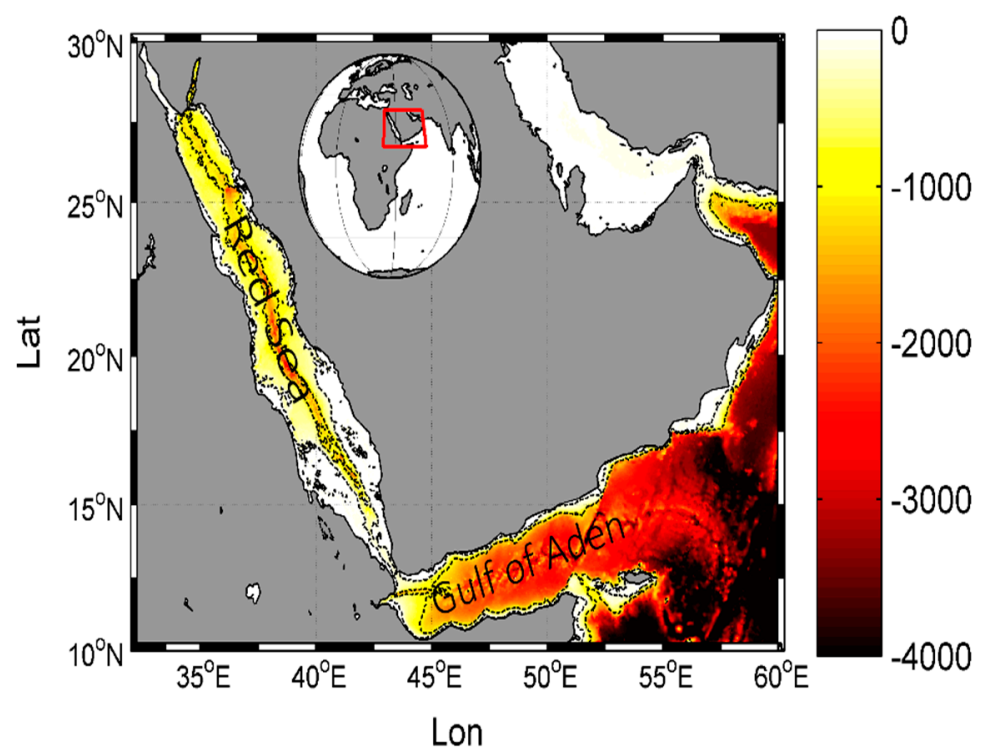

Figure 1. Map of the Red Sea (RS) and Gulf of Aden (GA) basins and the associated bathymetry in meters (m).

\subsection{Data}

In this study, we used gridded satellite altimetry SLA data that were obtained through archiving, validation, and interpretation of satellite oceanographic data (AVISO)-center localization satellite (CLS), Toulouse, France. The data are in a monthly time scale with $0.25^{\circ} \times 0.25^{\circ}$ spatial resolution and cover January 1993-December 2017.

We used ERA-interim $2 \mathrm{~m}$ air temperature and $10 \mathrm{~m}$ zonal and meridional wind from the European Centre for Medium-Range Weather Forecasts (ECMWF) in order to understand how the SLA links with large-scale circulations. This data set is widely used. It is a gridded reanalysis assimilated while using all of the available observations, including satellite, ships, drifting buoys, and land stations [39]. This dataset is available on a global scale with a temporal coverage from 1979 to the present on different spatial resolutions, but the data that were used here are from January 1993 to December 2017 on $0.5^{\circ} \times 0.5^{\circ}$ grids. For the thermocline depth $\left(20^{\circ} \mathrm{C}\right.$ isotherm $)$, we used the profile temperature data from the National Centers for Environmental Prediction (NCEP)-Global Ocean Data Assimilation System (GODAS). This dataset covers the same period and in $0.5^{\circ} \times 0.5^{\circ}$ grids.

We also used the time series of the monthly climate modes indices from both tropical (ENSO and Indian Ocean Dipole (IOD)) and polar EAWR regions corresponding to the same study period, which Table 1 describes.

\subsection{Methods}

The spatial variability of the dominant SLA patterns is investigated while using the EOF technique, which used for the first time in the climate fields by Lorenz (1956) [40]. It is considered to be a very effective tool, since the climate system composed of long-term statistical properties of the atmospheric/oceanic state 
that lead to high dimensionality. Thus, the challenge is to look at much smaller numbers by reducing the dimensionality to a few modes, which reflects most of the observed variance. A further most challenge is to link these modes to, for example, dynamic of large-scale climate circulations.

Simply, the EOF decomposes both the space and time field into orthogonal spatial patterns, called empirical eigenvectors (here is EOF1,2), which associated with eigenvalues to describe the fraction of explained variance and principal components (here is PC1,2) that tells how the amplitude of each EOF varies with time [41].

Table 1. Names and the sources of climate models used in this study.

\begin{tabular}{ccr}
\hline Name & Abbreviation & Sources \\
\hline MEI & Multivariate El Niño Index & https://www.esrl.noaa.gov/psd/enso/mei/table.html \\
\hline IOD & Indian Ocean Dipole & https:/www.esrl.noaa.gov/psd/gcos_wgsp/Timeseries/Data/dmi.long.data \\
\hline EAWR & East Atlantic-West Russian & ftp://ftp.cpc.ncep.noaa.gov/wd52dg/data/indices/eawr_index.tim \\
\hline
\end{tabular}

All the data were linearly detrended, normalized, and the seasonal cycle was removed, while the time series of climate indices were linearly detrended and normalized by standard deviation in order to have clear signals. From the entire monthly data set, we averaged the months, starting from December-January-February (winter), moving on to March-April-May (spring), June-July-August (summer), and ending with September-October-November (autumn).

\section{Results}

\subsection{The SLA Trend and the Dominant Modes}

Figure 2 shows the mean SLA over 25 years (1993-2017) during the winter, spring, summer, and autumn seasons. It is seen that the study area is characterized by inverse circulation, and the SLA rises in the winter and falls in the summer, which agrees with previous studies [21-26]. The maximum SLA range is about $0.4 \mathrm{~m}$ in the basin between winter and summer due to the inflow of fresh water from the AS and the combined effect of evaporation and outflow water to the AS, respectively.

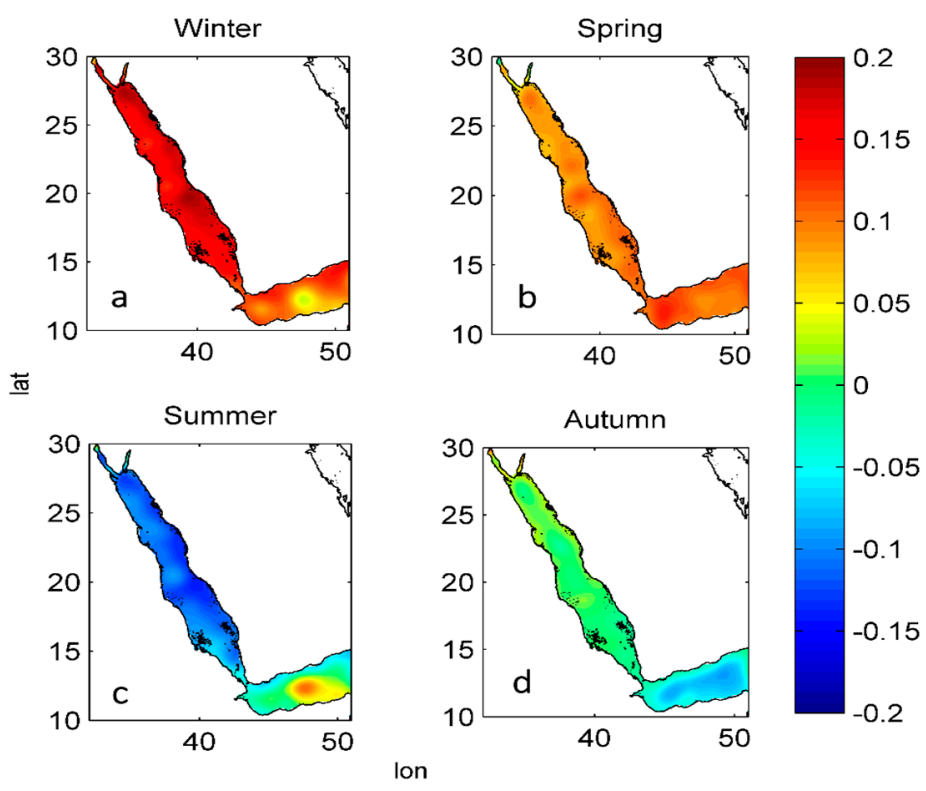

Figure 2. Cont. 

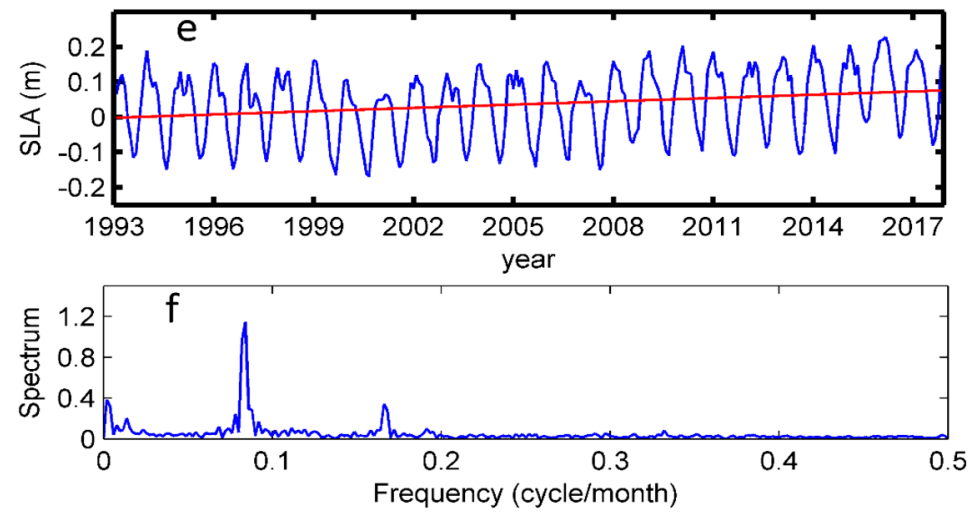

Figure 2. The mean sea level anomaly (SLA) pattern for the RS and GA during the winter, spring, summer, and autumn seasons (a-d) from 1993-2017. The time series of SLA with trend in red line for all area (e) and the spectral analysis of the time series (f).

The time series of the SLA reveals an increasing trend about $0.0028 \mathrm{my}^{-1}$ during the study period (Figure 2e), as compared to $0.0032 \mathrm{my}^{-1}$ as the global mean sea level trend from 1993 to 2010 [4]. Before fitting the trend, the significance of the time series has been tested while using the Mann-Kendall method and the result was statistically significant at $95 \%$. The spectral analyses (Figure 2f) of the SLA time series shows a significant spectrum peak on 12 months, which suggests that the annual cycle is dominant with the existence of a semi-annual cycle, although much weaker. Alawad et al. (2017) [27] used reanalysis data of sea level (53 years) and speculated that both cycles are associated to ENSO that was obtained from wavelet analysis.

The analysis of the dominant modes of the SLA patterns that reflects the spatiotemporal variability is presented while using EOF analysis (Figure 3). In the beginning, we included the study area that extends eastward to reach $58^{\circ} \mathrm{E}$ in the analysis; this area is outside the GA and characterized by strong eddies activity that has a bigger size and seems to be more intense and have a longer lifetime when compared to GA eddies. We found that the EOF results differed, and the explained variances were less than half of the current results, meaning that this area has a different circulation pattern that may possibly be connected to the Somali current, and finally we excluded it to $51.2^{\circ} \mathrm{E}$.

During winter, the first leading mode described $59 \%$ of the total variance, and the highest loading was observed over the Northern and Central RS, while the lowest loading over the GA (Figure 3a). The second leading mode shows $9 \%$ of the total variance (Figure 3e).

During spring, the first leading mode explained $69 \%$ of the total variance, the positive loading over the RS, while the GA loadings were close to zero (Figure 3b). When compared to first leading, the second spring leading mode reflects less variability, with only $6 \%$ of the total variance being explained (Figure 3f).

During summer, the first EOF mode that was characterized by homogeneous loading distribution explained $57 \%$ of the total variance, while the second EOF mode explained $9 \%$ of the total variance (Figure 3c,g).

During autumn, the EOF1 showed a higher explained variance $(71 \%)$ as compared to other seasons (Figure 3d). The GA loading was close to zero and it increased toward North RS. Same as that of the other seasons, autumn EOF2 was very small, and $6 \%$ was observed as explained variance (Figure $3 \mathrm{~h}$ ).

In general, all of the first leading modes reflected strong eddies activity in the RS and GA, which is a well-known property in the basins.

Figure 4 shows the times series of PC1 and PC2 corresponding to the EOF modes that reflect the variation over the study period. PC1 presents pronounced interannual variability, which can be inferred from evolution in time. The interesting result is that PC1 captures the strong La Niña event (1999-2001) during all seasons (Figure 4a-d). The PC2 time series seems to be smooth and it shows less variability that might refer to its low explained variances. 
From the EOF analysis (Figures 3 and 4), it is clear that the first leading modes throughout the seasons explained, on average, about $65 \%$ of the total variance, while the second mode was less than $10 \%$. That means that the second mode can be ignored, and we used the first leading mode for further analysis.

EOF1
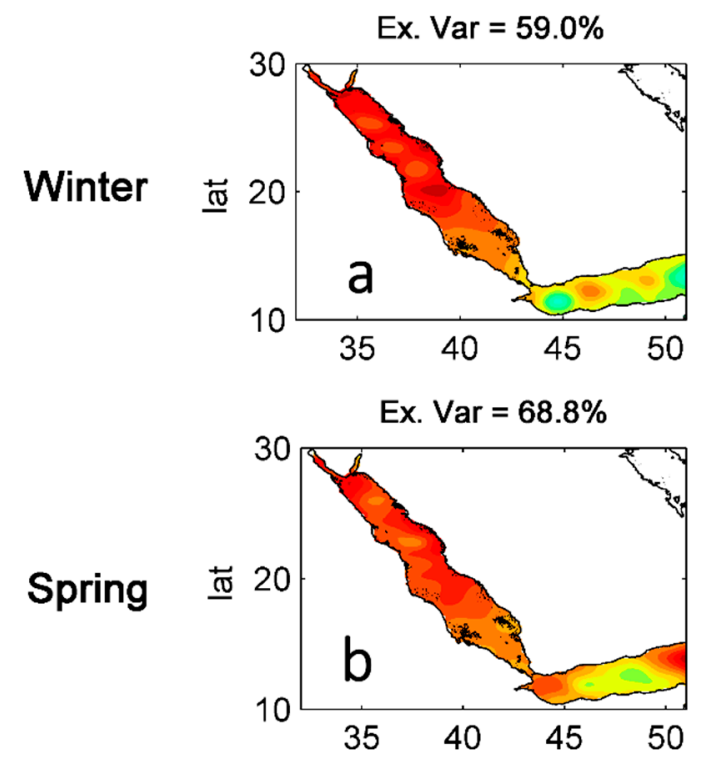

Ex. Var $=57.2 \%$

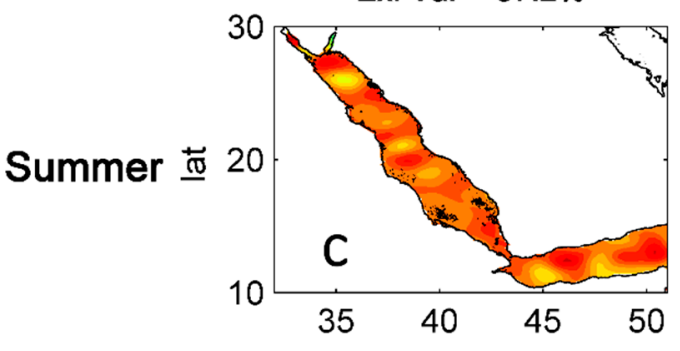

Ex. Var $=70.6 \%$

Autumn 뜨 20

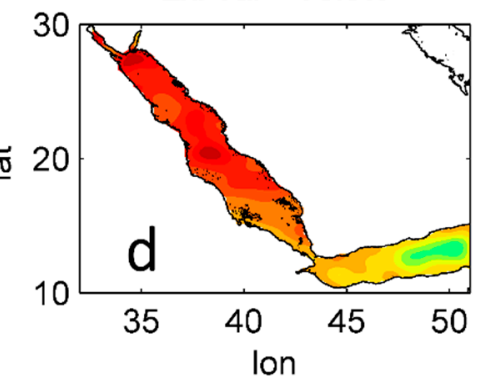

\section{EOF2}

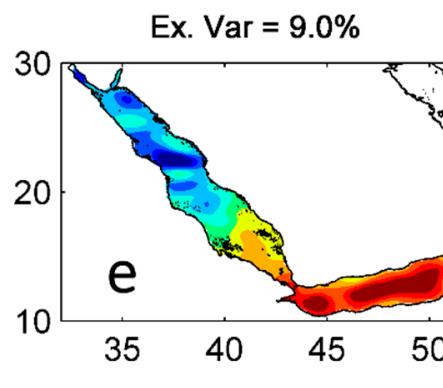

Ex. Var $=6.2 \%$
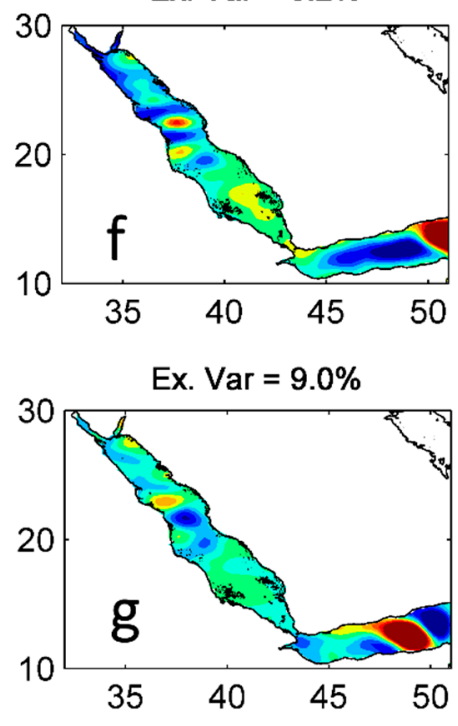

Ex. $\operatorname{Var}=6.0 \%$

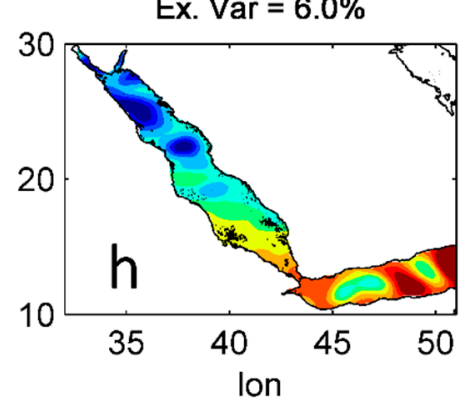

0.05

0.04

0.03

0.02

0.01

0

$-0.01$

$-0.02$

$-0.03$

$-0.04$

$-0.05$

Figure 3. Spatial patterns of the EOF1 (a-d) and EOF2 modes (e-h) of the SLA for the four seasons.

\subsection{Link between the SLA and Large-Scale Modes}

We evaluated the correlation of the PC1 time series of the SLA with the climate modes indices (Table 2) to investigate whether the SLA has a remote response or not. PC1 is positively correlated with ENSO through the MEI index during the spring, summer, and autumn seasons $(0.66,0.46$, and 0.57 , respectively) and negatively correlated with the winter and spring EAWR index $(-0.40$ and -0.46 , respectively). All of the results here are above the $95 \%$ significance level. Surprisingly, during the winter season, which is the peak of ENSO, PC1 shows a nonsignificant positive relation with MEI $(0.38$, $94 \%$ significance level). In addition to that, the correlation with the IOD, which principally influences 
the circulation in the AS, reflects a similar result during winter, and there is no relationship during other seasons. In support of our findings, Currie et al. (2013) [42] reported that ENSO (and not IOD) variability is predominantly related to chlorophyll in the Western AS.
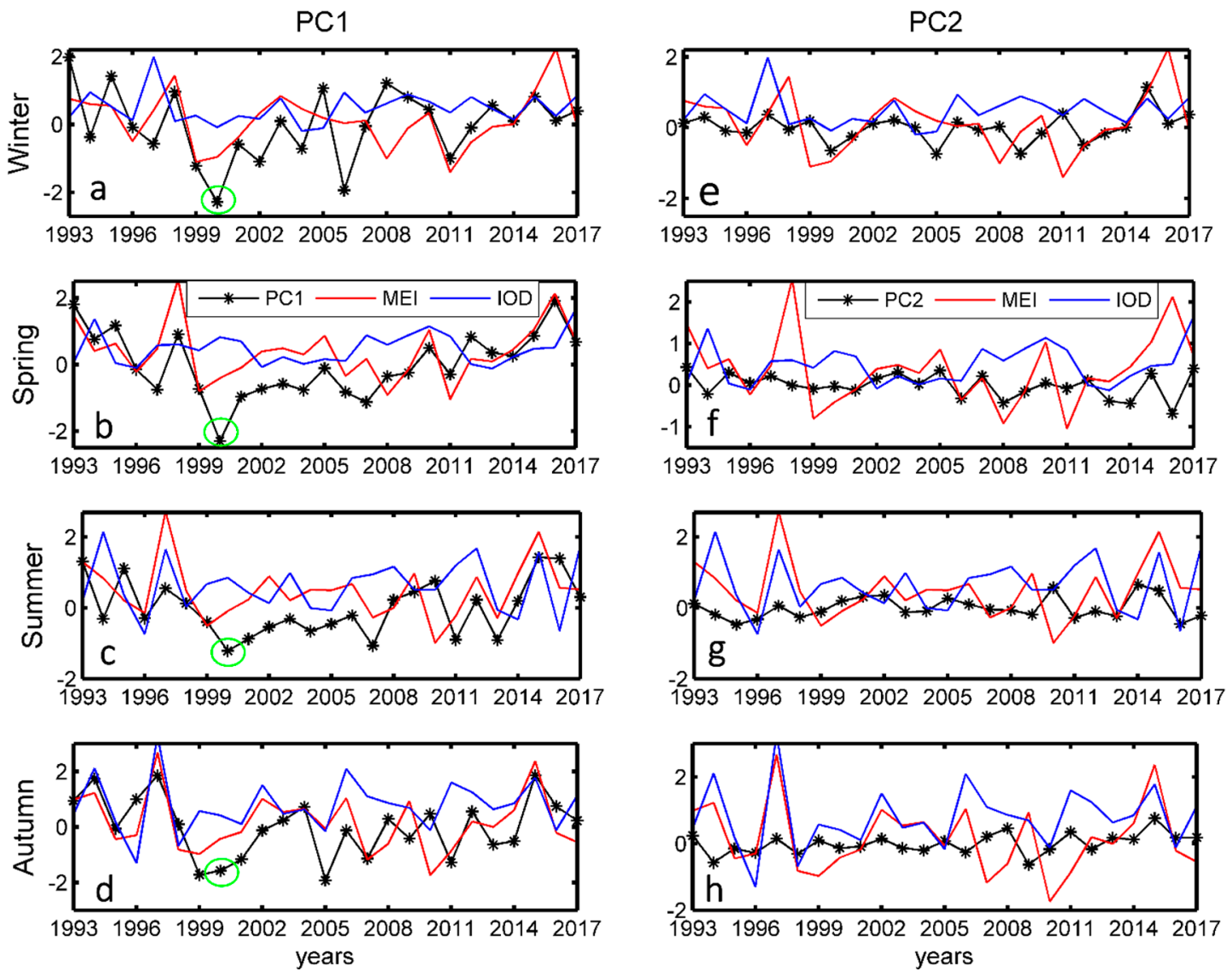

Figure 4. The times series of the principal components corresponding to the Empirical Orthogonal Function (EOF) modes. (a-d) are the revolution of PC1 during winter, spring, summer, and autumn, respectively; and, $(\mathbf{e}-\mathbf{h})$ is the same, but for PC2. The green circle the La Niña event. The IOD is multiplied by 2.5 .

Table 2. The correlation between the PC1, 2 and time series of different climate modes. Bold indicates significance at $95 \%$.

\begin{tabular}{cccc}
\hline EOF PCs & IOD & MEI & EAWR \\
\hline PC1 winter & $0.36(0.076)$ & $0.39(0.056)$ & $\mathbf{- 0 . 4 0}$ \\
\hline PC1 spring & & $\mathbf{0 . 6 6}$ & $\mathbf{- 0 . 4 7}$ \\
\hline PC1 summer & $\mathbf{0 . 4 6}$ & \\
\hline PC1 autumn & $\mathbf{0 . 5 7}$ & \\
\hline PC2 winter & & \\
\hline PC2 spring & & \\
\hline PC2 summer & & \\
\hline PC2 autumn & & \\
\hline
\end{tabular}

We assessed the same test with other climate indices, such as North Atlantic oscillation (NAO), Arctic oscillation (AO), and East Atlantic (EA), which influence the European climate, including North Africa, but we did not find a relationship. 
The spatial correlation between the raw SLA data and climate modes has been exhibited in order to reveal the different spatial responses as the study area was elongated meridionally (Figure 5). The MEI widely modulates the SLA through strong positive correlation throughout the year, especially during autumn and spring (>0.5). By contrast, the EAWR significantly modulates winter and spring SLA, mainly on the Northern RS (>-0.5).

There were no significant relations found during the other seasons for EAWR or for the IOD, $\mathrm{NAO}$, and $\mathrm{AO}$ at all. Both, taken together, the analysis emphasizes a link between the MEI and EAWR and the SLA in the RS and GA with significant correlations throughout the year.
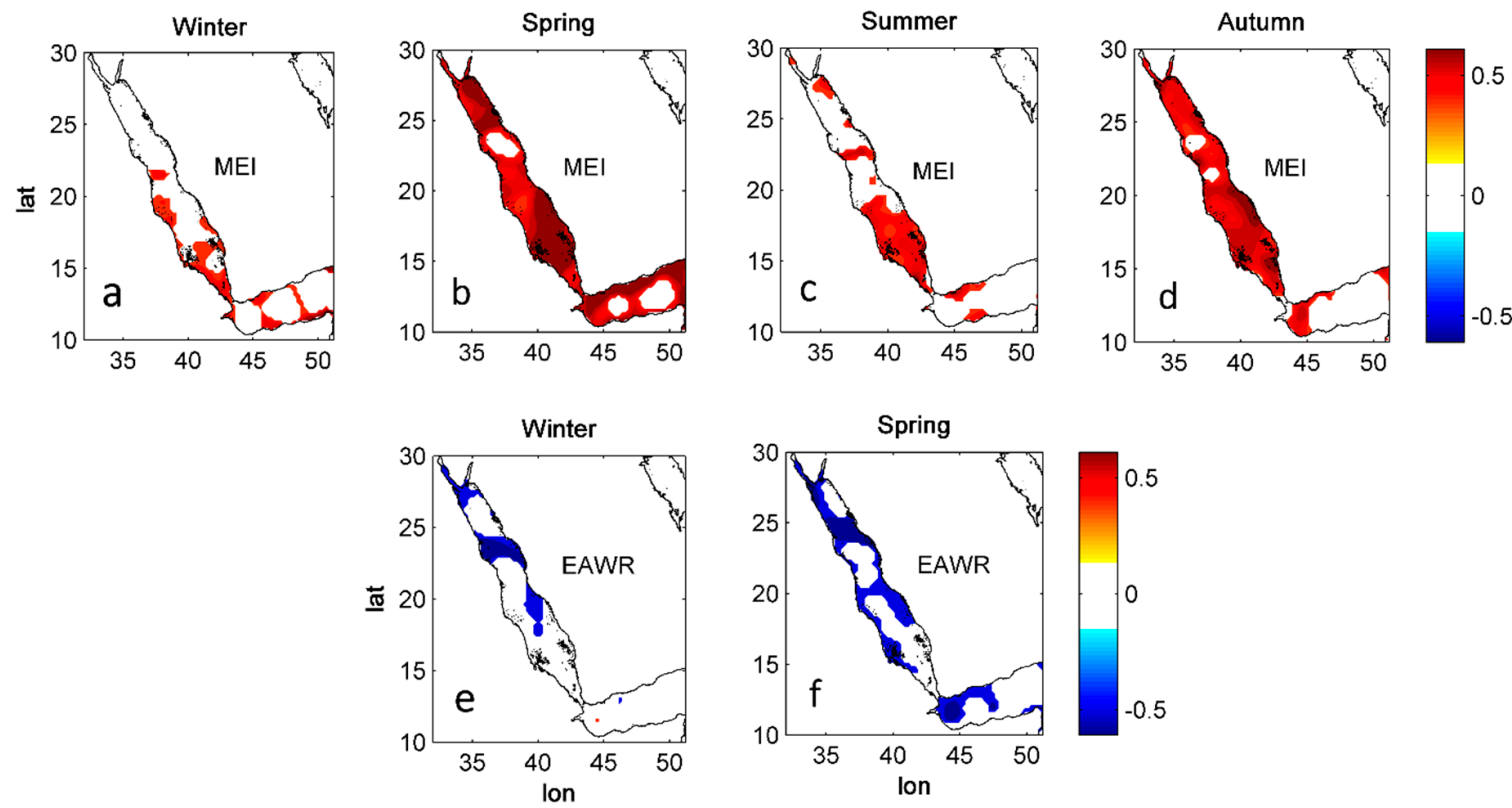

Figure 5. The spatial correlation pattern of raw SLA data with El Niño Southern Oscillation (ENSO) during all seasons (a-d) and East Atlantic/West Russia (EAWR) during winter and spring seasons (e, f). Only 95\% significance level results are plotted.

\subsection{The Physical Mechanisms}

\subsubsection{The Relation with SLA, Wind and $20{ }^{\circ} \mathrm{C}$ isotherm in the IO}

The physical mechanisms that connect the SLA with large-scale modes were investigated through linear regression analysis of PC1 onto the SLA, surface wind, and thermocline depth in the IO (Figures 6 and 7).

The regression maps of the SLA reveal a dipole-like pattern, a strong positive relationship (values up to 0.7 ) on the western side of the $\mathrm{IO}$, and a relatively weak negative relationship (values up to -0.4) in the eastern side (Figure 6) in all seasons, except summer, where the positive relationship covers a wide area in the IO. In addition, there is a notable weak positive relation during winter that is associated with weak and distorted shape of wind compared to other seasons (Figure 6a) that may infer a weakening of the physical mechanism that drives the SLA during this season. Furthermore, the regression with zonal wind yields northeasterly/southeasterly flow, which directed opposite to the mean low-level circulation of IO. Meaning that, an increase of the sea level over the West $\mathrm{IO}$ (west of $80^{\circ} \mathrm{E}$ ) associated with northeasterly/southeasterly wind can be seen as a possible cause for the increasing SLA in the GA and RS, as they only exchange their water masses with IO. It is well known that both sea level [43] and wind [44-46] over IO are closely related to ENSO via the atmospheric bridge [44,47]. Since the IO has such a basinwide response to ENSO, it is not surprising to notice the chlorophyll concentration over GA and RS has been controlled by ENSO through the northeasterly/southeasterly wind [48]. 
The wind-inducing sea level also extended to inside the RS. It was found that the wind blowing to the mean circulation in the Southern and Central RS during the spring and autumn season could drive the sea level to the northern basin (Figure $6 b, c)$.

Figure 7 shows the regression of PC1 onto a thermocline depth, denoted by a $20{ }^{\circ} \mathrm{C}$ isotherm depth. The map again reveals the dipole-like pattern, with a positive relationship over the West IO and negative relationship over the East IO. The positive implies a deepening thermocline, while the negative implies a shoaling thermocline. The dipole shape of the thermocline depth shows the expected responses of the IO arising from wind-forced Rossby waves during El Niño events [49]. The slow westward propagation of Rossby waves over IO (that may takes few months) due to El Niño-induced wind stress can be prolonged after El Niño demise [50]. Here, the significant equatorial upwelling Rossby wave (negative relation) in the Eastern IO reaches its peak by splitting into two waves during winter, while it intensified during the summer and autumn seasons (Figure 7a,c,d respectively).

In brief, Figures 6 and 7 provide a significant linkage between the SLA in the GA and RS and IO throughout the SLA, wind circulation, and thermocline depth, with the contribution of the local surface wind inside the basins.

The studies that noticed that the IO circulations that are closely related to Pacific Ocean variability [43-46,49-51] encourage us to the show the direct tight coupling ENSO and wind in IO, including GA and RS. In Figure 8, we show the correlation between the zonal wind in the IO and MEI. The results demonstrate a clear negative relationship over the AS and GA during autumn and spring (Figure 8b,d), meaning that during positive (negative) MEI phases, the easterlies that control the horizontal water mass inflow from the Arabian Sea to GA and RS are intensified (reduced). The relation is weak during summer (Figure 8c), and almost no relation was found during winter (Figure 8a). The winter result is quite the opposite to that achieved by Raitsos et al. (2015) [48], where a strong negative correlation was observed from 1950 to 2010. To confirm the above finding, we used the same data that they used (NCEP/National Center for Atmospheric Research (NCAR) monthly reanalysis zonal wind), but from 1993 to 2015, and it supported our result.
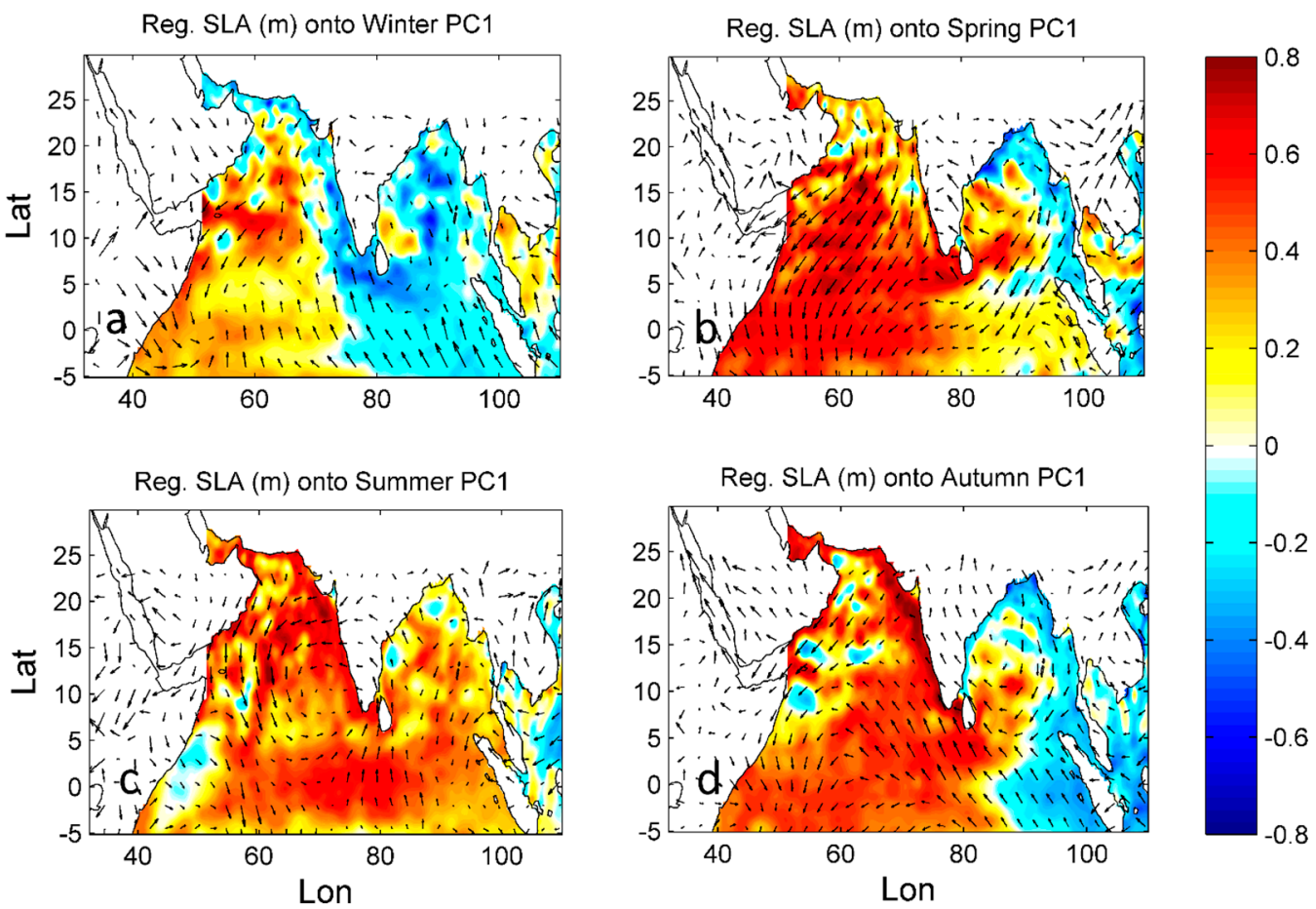

Figure 6. The spatial regression pattern of PC1 (a-d) onto surface wind and SLA (shaded) in the IO during winter, spring, summer, and autumn, respectively. Zero lines are omitted. 

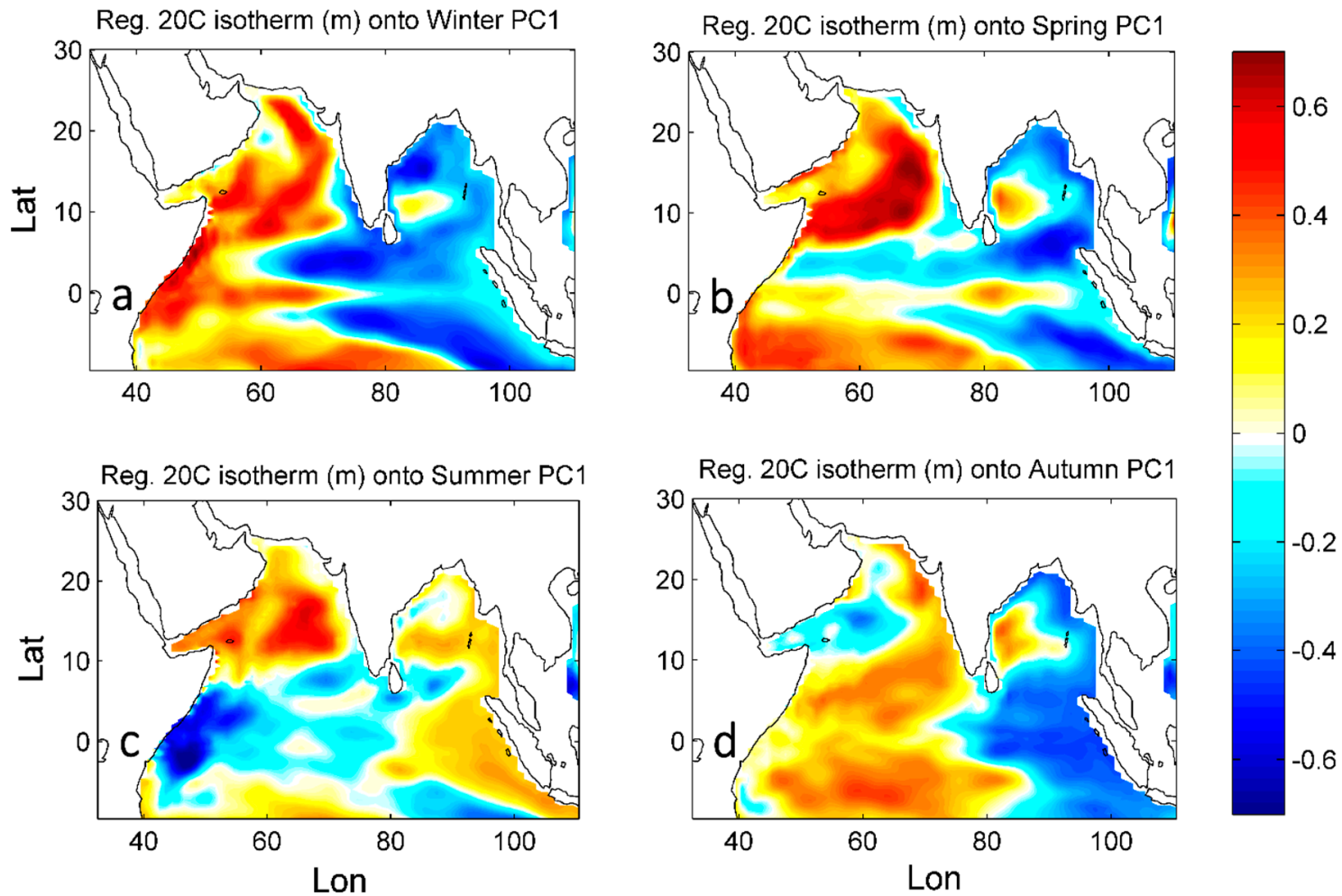

Figure 7. Same as in Figure 6, but for the thermocline depth denoted by $20^{\circ} \mathrm{C}$ isotherm. Zero lines are omitted.
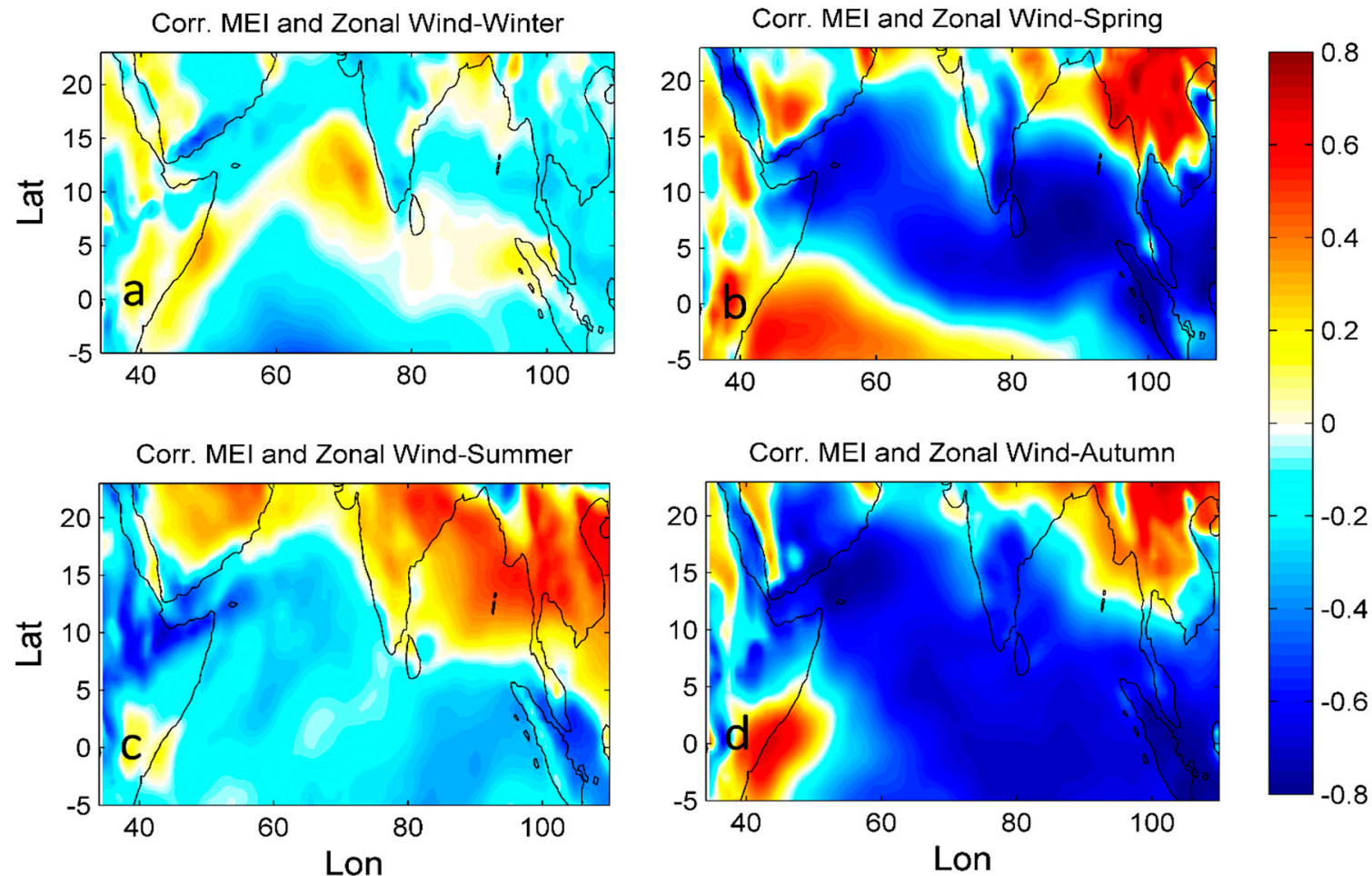

Figure 8. The spatial correlation pattern of multivariate El Niño index (MEI) and zonal wind in the Indian Ocean (IO) (a-d) during winter, spring, summer, and autumn, respectively. Zero lines are omitted.

Overall, Figure 8 provides evidence of El Niño-induced wind stress that affects the IO circulations (increase sea level and thermocline depth) also extending to IO marginal basins. Moreover, the 
weakening and/or shift in the relation between the ENSO and IO circulations (1993-2017) during the winter season affected the relation between the GA and RS and IO in the same season.

\subsubsection{The Relationship with Global Temperature}

In this analysis, we constructed the correlation map between PC1 of the SLA and global $2 \mathrm{~m}$ air temperature to investigate whether there is a relation between SLA and any far field phenomena. Here, the air temperature was considered to be an indicator for their position and for a much wider view, either the phenomena in the sea or land.

The analysis accompanied spatial displacements of clear walker circulation (Figure 9). The positive correlations were in an elongated band over the eastern and central part of the Pacific Ocean. This band was flanked by negative correlation in the north and south of the equatorial Pacific, which may enhance the Hadley cell during ENSO events. Moreover, the polar climate mode, including NAO, EAWR, and $\mathrm{AO}$, tended to decrease the SLA, which is clear from the insignificant weak negative correlation, which can be ignored in this work. Through this analysis, we demonstrated that the Pacific Ocean plays a significant role in SLA variability in the basins, mainly through remote drivers through the walker and Hadley cells. These results confirmed our finding in Figures 6-8 that ENSO influences the sea level variations over the GA and RS, where the signal transferred to the IO and further to the RS and GA. The easterly wind over IO that drive the SLA (Figure 6) and trigger Rossby waves (Figure 7) can be observed in advance of the appearance of positive SST anomalies in the equatorial Pacific Ocean during positive phase of ENSO [44,52,53].
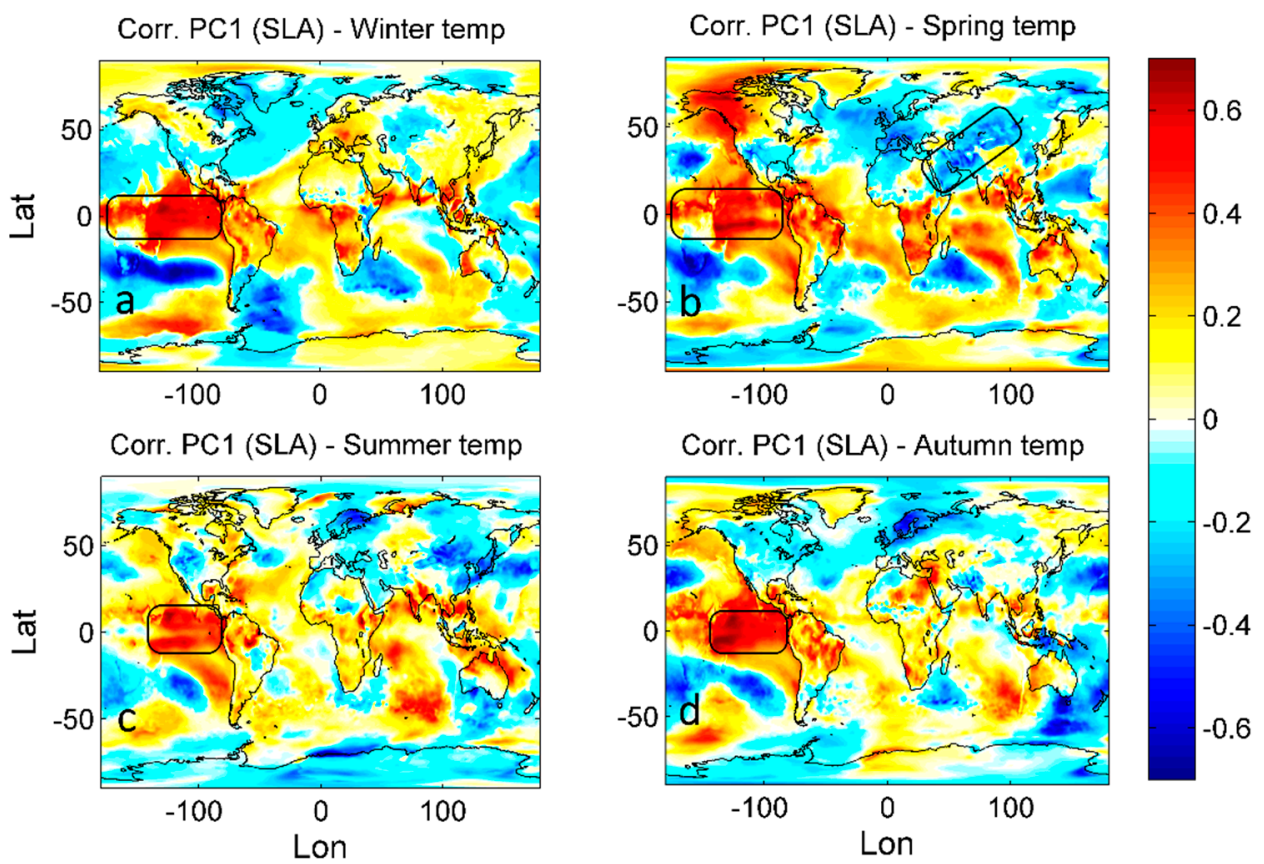

Figure 9. The spatial correlation pattern of PC1 with global temperature during the winter, spring, summer, and autumn seasons.

\section{Discussion}

Using SLA data, we present a clear perspective on the impact of a large-scale mode on the RS and GA. The time series of PC1 of SLA reflects the strong La Niña 2000-2001 event through clear SLA decreasing during all seasons.

The correlation analysis reveals that ENSO and EAWR are the major contributors to SLA variability. The positive phase of the SLA was associated with the positive phase of ENSO and negative phase of EAWR. Seasonally, ENSO modulated the SLA during all seasons, while EAWR modulation during winter and spring. Recently, similar results came out: Shanas et al. (2017) [54] identified that MEI is 
one of the major modes to influence the significant wave heights in the Southern RS, while the NAO and EAWR are major modes in the Northern RS, which are locally generating strong wind speed by the advection of cold air masses from Europe. From the global view, the nonseasonal variations of global mean sea level are significantly correlated with ENSO [14]. Furthermore, there is consistency between ENSO and EAWR in modulating the SLA during the spring season in the Northern RS. The linkage between ENSO and EAWR is through the East Asian winter monsoon, which is composed of two parts, one that is related to ENSO and the other related to the Siberian High and East Asian trough [34]. In addition, the correlation exhibited a weak relation with NAO which is different from those found by Karnauskas and Jones (2018) [55], who mentioned that the NAO impact on the SST in the RS concentrated on the small area north of $25^{\circ} \mathrm{N}$. The high sensitivity of SST to the atmospheric circulation as compared to SLA and area limitation might the possible reason for the insignificant NAO impact in this work.

We found that the sea level, surface wind, and thermal expansion in the IO seems to have a significant role in modulating the SLA in the RS and GA. The physical mechanism by which ENSO influences the SLA is identifiable by the regression correlation. Usually, in the normal case over the Pacific Ocean, the sea level pressure in the east is higher than that in the west, for that, and it forces the trade wind to follow the equator by the pressure difference from east to west (easterly). By the same idea, the wind in the IO blows from west to east (westerly). However, during positive events, the sea level pressure over the West Pacific, including South Asian countries in the East IO, becomes higher than in the Eastern Pacific and Western IO. This situation forces the normal surface wind in the IO either to be weak westerly or to completely change direction to easterly. Previous studies reported vividly that the dominant mode of surface wind and SST in the IO is closely related to ENSO [49,51,56-58].

It is well known that such a strong easterly wind in the IO can trigger the Rossby wave in the West Sumatra Coast that deepens the thermocline and advects the warm water to increase the SLA in the West IO during ENSO [56]. Similar results were observed in this work through regression analysis; the SLA increased in the West IO through the combined effect of wind and thermal expansion and then extended to include the RS and GA. Furthermore, these results are consistent with the findings of Chambers et al. (1999) [59] that PC1 of SLA in the IO coevolves with average zonal wind stress anomaly and PC1 of SST. On other hand, our results show the importance of the thermal expansion of the IO that supports the SLA in the RS and GA. The results are in accordance with those that were observed in the IO by Salim et al. (2012) [60], who demonstrated strong coherence between the dominant modes of steric sea level and the SLA. Their study suggested that the steric sea level variability has strong control on the variability of SLA in the IO and thereafter to the GA and RS.

Along that line, a new mechanism reported the synergy of the winter monsoon in the AS to regulate RS fertility [48]. In this effort, the chlorophyll concentration and the duration of the phytoplankton-growing season were found to be controlled by monsoon wind through the horizontal advection of fertile waters from the $\mathrm{IO}$, which corresponds to our finding. In addition, the phytoplankton biomass during winter increased by $75 \%$ during the prolonged positive phases of ENSO events from 1998 to 2010. Recent support came from Karnauskas and Jones (2018) [55], who found that the positive phase of PC1 that resulted from the entire RS SST during winter is associated with broad warm surface air temperatures that cover a wide adjacent area. This warming is linked to ENSO and coincides with the local surface wind opposite the mean wind system (northwesterly ward, including the Central and Northern RS). In general, they suggested that the SST of the RS is a manifestation of ENSO, EAWR, and NAO and footprint [55], where later two considered as the major teleconnection patterns in Europe that influences precipitation and air temperature [61].

Our results increase the possibilities that, with warmer climate conditions, the GA and RS sea level will continue increasing, since El Niño frequency events are predicted to increase due to global warming [62]. Furthermore, the RS ecosystem could be more productive, since the nutrient abundance depends on the horizontal advection of easterly wind from the IO, which intensified during El Niño events [48]. 
The key aspect of a weak relation between PC1 of the SLA and the SLA and surface wind over the IO during the winter season (Figure 6a) is the notable weak relation between the zonal wind over the IO and ENSO that drive the SLA to the GA and RS (Figure 8a). The inverse relationship between the zonal wind over IO and ENSO has been well documented, especially before the mid-1970s [63]. Weak (strong) wind typically occurs during El Niño (La Niña) [64,65]. However, after the early 1980s, there was a weakening and shift that were included behind the surface wind to the SST $[58,66]$, which means that this shift took place over 30 years ago and still continues, which is consistent with our results. Nakamura et al. (2009) [67] suggested that a warming of the Western IO has driven the observed shift by acting as a barrier for ENSO influencing the IO circulation, including the GA and RS.

In spite of the importance of large-scale circulations, the local drivers cannot be ignored. Comparable findings speculate the local positive feedback in the RS that is initially triggered by the large-scale mode and then locally amplified to modulate different variables, including SST and general circulation [55]. Prior studies have noted the importance of local phenomena in influencing the circulation in the RS, such as the evaporation rate, which triggers the thermocline to influence the circulation [68] and the local wind system, which is responsible for the SLA and SST on a seasonal time scale $[21,24]$.

It remains an open question to which extent the variation of surface wind, SLA, SST, and thermal expansion in the IO can contribute to the SLA in the RS and GA throughout the time scale. Hence, a sensitivity experiment using a regional coupled ocean-atmosphere model might be able to resolve such a separation mechanism.

\section{Conclusions}

Several studies discussed the controlling factors of SLA variability in the RS and GA from local views and believed that the surface wind, evaporation, and water exchange with the AS and IO are the main factors [21-25]. Furthermore, few studies linked the annual and semi-annual SLA signals with large-scale circulation while using reanalysis data without explanation of the physical mechanisms [26,27]. The new perspective in this study is the connection between the SLA and large-scales modes, with explanation of the physical mechanisms using satellite altimetry data (AVISO).

The main findings of this study can be summarized, as follows:

- the SLA reflects the annual and semi-annual cycle, which agrees with previous studies;

- the first leading mode throughout the seasons explained, on average, about $65 \%$ of the total variance, while their PCs clearly capture the strong La Niña event (1999-2001) during all seasons; and,

- the SLA showed a strong positive relation with ENSO during all seasons and a strong negative relation with EAWR during winter and spring.

Our results explain the mechanisms of SLA variability over the RS and GA. The unusual strong easterly wind that was displaced north of the equator generated an upwelling area of cold water near the coast of Sumatra and drove both warm surface and deep water westward. As a result of that, the SST and thermal expansion increase toward the West IO and AS, raising the SLA over the RS and GA. This process could explain the increase of the SLA in the basin during the positive phase of ENSO. These mechanisms were proposed earlier in the IO; the new progress in this study is that we confirmed it over the RS and GA.

Based on the above findings, the Pacific Ocean and IO both enhanced the SLA in the RS and GA. As the Pacific Ocean is more energetic, we suggest that it holds the signals sources, and then transfers them to the IO. These considerations might lead to inference that ENSO influences not only the IO, but can also be extended to adjacent marginal basins, like the RS and GA. Moreover, the signal of the extratropical climate mode is also presented by the EAWR pattern due to meridional extension of the study area. Thus, we argue that the GA and RS are suitable areas for studying the interaction of large-scale climate models in interannual and interdecadal time scales. Our results support the possibilities of increasing sea level and productivity in the two basins due to above normal 
advection of fertile water from IO, which highlights the importance of horizontal nutrient transfer in the tropics under a warmer climate scenario. Finally, a sensitivity experiment using a regional coupled ocean-atmosphere model is needed to separate between the contribution of surface wind, SST, and thermal expansion on the RS and GA SLA.

Author Contributions: Conceptualization, K.A.A. and A.M.A.-S.; methodology, K.A.A., M.I., G.L. and M.A.A.; software and formal analysis, K.A.A.; validation and outcome investigation, All Authors; writing-original draft preparation, K.A.A.; writing-review and editing, All Authors; supervision, A.M.A.-S.

Funding: This research received no external funding.

Acknowledgments: The authors are highly appreciating the AVISO, ECMWF, GODAS and NOAA-CPC teams for making the data available. The first author would like to thank the Deanship of Graduate Studies (DGS), HPC Center (Azizi Supercomputer)-King Abdulaziz University-Saudi Arabia, Centre of Excellence (CofE)-NF-POGO-Alfred Wegener Institute Helmholtz Centre for Polar and Marine Research (AWI)-Germany for various effort supporting this research.

Conflicts of Interest: The authors declare no conflict of interest.

\section{References}

1. Church, J.A.; White, N.J. A 20th century acceleration in global sea-level rise. Geophys. Res. Lett. 2006, 33, 33. [CrossRef]

2. Church, J.A.; White, N.J. Sea-level rise from the late 19th to the early 21st century. Surv. Geophys. 2011, 32, 585-602. [CrossRef]

3. Church, J.A.; Clark, P.U.; Cazenave, A.; Gregory, J.M.; Jevrejeva, S.; Levermann, A.; Merrifield, M.A.; Milne, G.A.; Nerem, R.S.; Nunn, P.D.; et al. Sea level change. Climate change 2013: The physical science basis. In Contribution of Working Group I to the Fifth Assessment Report of the Intergovernmental Panel on Climate Change; Cambridge University Press: Cambridge, UK; New York, NY, USA, 2013; pp. 1137-1216.

4. Pachauri, R.K.; Allen, M.R.; Barros, V.R.; Broome, J.; Cramer, W.; Christ, R.; Church, J.A.; Clarke, L.; Dahe, Q.; Dasgupta, P.; et al. Climate change 2014: Synthesis report. In Contribution of Working Groups I, Ii and Iii to the Fifth Assessment Report of the Intergovernmental Panel on Climate Change; IPCC: Geneva, Switzerland, 2014.

5. Katsman, C.A.; Hazeleger, W.; Drijfhout, S.S.; van Oldenborgh, G.J.; Burgers, G. Climate scenarios of sea level rise for the northeast Atlantic Ocean: A study including the effects of ocean dynamics and gravity changes induced by ice melt. Clim. Chang. 2008, 91, 351-374. [CrossRef]

6. Stammer, D.; Cazenave, A.; Ponte, R.M.; Tamisiea, M.E. Causes for contemporary regional sea level changes. Annu. Rev. Mar. Sci. 2013, 5, 21-46. [CrossRef]

7. Carson, M.; Köhl, A.; Stammer, D.; Slangen, A.B.A.; Katsman, C.A.; Van de Wal, R.S.W.; Church, J.; White, N. Coastal sea level changes, observed and projected during the 20th and 21st century. Clim. Chang. 2016, 134, 269-281. [CrossRef]

8. Cui, M.; STORCH, H.V.; Zorita, E. Coastal sea level and the large-scale climate state A downscaling exercise for the Japanese Islands. Tellus A 1995, 47, 132-144. [CrossRef]

9. Nerem, R.S.; Chambers, D.P.; Leuliette, E.W.; Mitchum, G.T.; Giese, B.S. Variations in global mean sea level associated with the 1997-1998 ENSO event: Implications for measuring long term sea level change. Geophys. Res. Lett. 1999, 26, 3005-3008. [CrossRef]

10. Antonov, J.I.; Levitus, S.; Boyer, T.P. Thermosteric sea level rise. Geophys. Res. Lett. 2005, 32, 1955-2003.

11. Landerer, F.W.; Jungclaus, J.H.; Marotzke, J. El Niño-Southern Oscillation signals in sea level, surface mass redistribution, and degree-two geoid coefficients. J. Geophys. Res. Space Phys. 2008, 113. [CrossRef]

12. Moon, J.H.; Song, Y.T.; Lee, H. PDO and ENSO modulations intensified decadal sea level variability in the tropical Pacific. J. Geophys. Res. Ocean. 2015, 120, 8229-8237. [CrossRef]

13. Hamlington, B.D.; Cheon, S.H.; Thompson, P.R.; Merrifield, M.A.; Nerem, R.S.; Leben, R.R.; Kim, K.-Y.; Kim, K. An ongoing shift in Pacific Ocean sea level. J. Geophys. Res. Ocean. 2016, 121, 5084-5097. [CrossRef]

14. Piecuch, C.G.; Quinn, K.J. El Niño, La Niña, and the global sea level budget. Ocean. Sci. 2016, 12, $1165-1177$. [CrossRef]

15. Nidheesh, A.G.; Lengaigne, M.; Vialard, J.; Izumo, T.; Unnikrishnan, A.S.; Meyssignac, B.; Hamlington, B.; Montegut, C.D.B.; Montegut, C.B. Robustness of observation-based decadal sea level variability in the Indo-Pacific Ocean. Geophys. Res. Lett. 2017, 44, 7391-7400. [CrossRef] 
16. Arpe, K.; Bengtsson, L.; Golitsyn, G.S.; Mokhov, I.I.; Semenov, V.A.; Sporyshev, P.V. Connection between Caspian Sea level variability and ENSO. Geophys. Res. Lett. 2000, 27, 2693-2696. [CrossRef]

17. Stanev, E.V.; Peneva, E.L. Regional sea level response to global climatic change: Black Sea examples. Glob. Planet. Chang. 2001, 32, 33-47. [CrossRef]

18. Zanchettin, D.; Rubino, A.; Traverso, P.; Tomasino, M. Teleconnections force interannual-to-decadal tidal variability in the Lagoon of Venice (northern Adriatic). J. Geophys. Res. Space Phys. 2009, 114. [CrossRef]

19. Calafat, F.M.; Chambers, D.P.; Tsimplis, M.N. Mechanisms of decadal sea level variability in the eastern North Atlantic and the Mediterranean Sea. J. Geophys. Res. Space Phys. 2012, 117. [CrossRef]

20. Tsimplis, M.N.; Calafat, F.M.; Marcos, M.; Jorda, G.; Gomis, D.; Fenoglio-Marc, L.; Struglia, M.V.; Josey, S.A.; Chambers, D. The effect of the NAO on sea level and on mass changes in the Mediterranean Sea. J. Geophys. Res. Space Phys. 2013, 118, 944-952. [CrossRef]

21. Patzert, W.C. Wind-induced reversal in Red Sea circulation. Deep. Sea Res. Oceanogr. Abstr. 1974, $21,109-121$. [CrossRef]

22. Sultan, S.A.R.; Ahmad, F.; El-Hassan, A. Seasonal variations of the sea level in the central part of the Red Sea. Estuar. Coast. Shelf Sci. 1995, 40,1-8. [CrossRef]

23. Sultan, S.A.R.; Ahmad, F.; Nassar, D. Relative contribution of external sources of mean sea-level variations at Port Sudan, Red Sea. Estuar. Coast. Shelf Sci. 1996, 42, 19-30. [CrossRef]

24. Sofianos, S.S.; Johns, W.E. Wind induced sea level variability in the Red Sea. Geophys. Res. Lett. 2001, 28, 3175-3178. [CrossRef]

25. Sultan, S.A.R.; Elghribi, N.M. Sea Level Changes in the Central Part of the Red Sea; CSIR: New Delhi, India, 2003.

26. Manasrah, R.; Hasanean, H.M.; Al-Rousan, S. Spatial and seasonal variations of sea level in the Red Sea, 1958-2001. Ocean Sci. J. 2009, 44, 145-159. [CrossRef]

27. Alawad, K.; Alsaafani, M.A.; Al-Subhi, A.M.; Alraddadi, T.M. Signatures of Tropical Climate Modes on the Red Sea and Gulf of Aden Sea Level; NISCAIR-CSIR: New Delhi, India, 2017.

28. Al-Rousan, S.; Al-Moghrabi, S.; Pätzold, J.; Wefer, G. Environmental and biological effects on the stable oxygen isotope records of corals in the northern Gulf of Aqaba, Red Sea. Mari. Ecol. Prog. Ser. 2002, 239, 301-310. [CrossRef]

29. Al-Rousan, S.; Al-Moghrabi, S.; Pätzold, J.; Wefer, G. Stable oxygen isotopes in Porites corals monitor weekly temperature variations in the northern Gulf of Aqaba, Red Sea. Coral Reefs 2003, 22, 346-356. [CrossRef]

30. Arz, H.W.; Lamy, F.; Pätzold, J.; Müller, P.J.; Prins, M. Mediterranean moisture source for an Early-Holocene humid period in the northern Red Sea. Science 2003, 300, 118-121. [CrossRef] [PubMed]

31. Al-Rousan, S.; Felis, T.; Manasrah, R.; Al-Horani, F. Seasonal variations in the stable oxygen isotopic composition in Porites corals from the northern Gulf of Aqaba, Red Sea. Geochem. J. 2007, 41, 333-340. [CrossRef]

32. Felis, T.; Pätzold, J.; Loya, Y.; Fine, M.; Nawar, A.H.; Wefer, G. A coral oxygen isotope record from the northern Red Sea documenting NAO, ENSO, and North Pacific teleconnections on Middle East climate variability since the year 1750. Paleoceanogr. Paleoclimatology 2000, 15, 679-694. [CrossRef]

33. Rimbu, N.; Lohmann, G.; Felis, T.; Pätzold, J. Arctic Oscillation signature in a Red Sea coral. Geophys. Res. Lett. 2001, 28, 2959-2962. [CrossRef]

34. Ionita, M.; Felis, T.; Lohmann, G.; Rimbu, N.; Pätzold, J. Distinct modes of East Asian Winter Monsoon documented by a southern Red Sea coral record. J. Geophys. Res. Space Phys. 2014, 119, 1517-1533. [CrossRef]

35. Papadopoulos, V.P.; Abualnaja, Y.; Josey, S.A.; Bower, A.; Raitsos, D.E.; Kontoyiannis, H.; Hoteit, I. Atmospheric forcing of the winter air-sea heat fluxes over the northern Red Sea. J. Clim. 2013, 26, 1685-1701. [CrossRef]

36. Abualnaja, Y.; Papadopoulos, V.P.; Josey, S.A.; Hoteit, I.; Kontoyiannis, H.; Raitsos, D.E. Impacts of climate modes on air-sea heat exchange in the Red Sea. J. Clim. 2015, 28, 2665-2681. [CrossRef]

37. Morcos, S.A. Physical and chemical oceanography of the Red Sea. Oceanogr. Mar. Biol. Annu. Rev. 1970, 8 , 73-202.

38. Al Saafani, M.A.; Shenoi, S.S.C. Water masses in the Gulf of Aden. J. Oceanogr. 2007, 63, 1-14. [CrossRef]

39. Dee, D.P.; Uppala, S.M.; Simmons, A.J.; Berrisford, P.; Poli, P.; Kobayashi, S.; Andrae, U.; Balmaseda, M.A.; Balsamo, G.; Bauer, P. The ERA-Interim reanalysis: Configuration and performance of the data assimilation system. Q. J. R. Meteorol. Soc. 2011, 137, 553-597. [CrossRef] 
40. Lorenz, E.N. Empirical Orthogonal Functions and Statistical Weather Prediction; Massachusetts Institute of Technology: Cambridge, MA, USA, 1956.

41. Björnsson, H.; Venegas, S.A. A manual for EOF and SVD analyses of climatic data. CCGCR Rep. 1997, 97, 112-134.

42. Currie, J.C.; Lengaigne, M.; Vialard, J.; Kaplan, D.M.; Aumont, O.; Naqvi, S.W.A.; Maury, O. Indian Ocean dipole and El Nino/southern oscillation impacts on regional chlorophyll anomalies in the Indian Ocean. Biogeosciences 2013, 10, 6677-6698. [CrossRef]

43. Saji, N.H.; Xie, S.P.; Yamagata, T. Tropical Indian Ocean variability in the IPCC twentieth-century climate simulations. J. Clim. 2006, 19, 4397-4417. [CrossRef]

44. Klein, S.A.; Soden, B.J.; Lau, N.-C. Remote sea surface temperature variations during ENSO: Evidence for a tropical atmospheric bridge. J. Clim. 1999, 12, 917-932. [CrossRef]

45. Saji, N.H.; Yamagata, T. Structure of SST and surface wind variability during Indian Ocean dipole mode events: COADS observations. J. Clim. 2003, 16, 2735-2751. [CrossRef]

46. Du, Y.; Xie, S.-P.; Huang, G.; Hu, K. Role of air-sea interaction in the long persistence of El Niño-induced north Indian Ocean warming. J. Clim. 2009, 22, 2023-2038. [CrossRef]

47. Alexander, M.A.; Bladé, I.; Newman, M.; Lanzante, J.R.; Lau, N.-C.; Scott, J.D. The atmospheric bridge: The influence of ENSO teleconnections on air-sea interaction over the global oceans. J. Clim. 2002, 15, 2205-2231. [CrossRef]

48. Raitsos, D.E.; Yi, X.; Platt, T.; Racault, M.-F.; Pradhan, Y.; Papadopoulos, V.; Sathyendranath, S.; Hoteit, I.; Brewin, R.J.W. Monsoon oscillations regulate fertility of the Red Sea. Geophys. Res. Lett. 2015, 42, 855-862. [CrossRef]

49. Liu, L.; Feng, L.; Wu, Y.; Yu, W.; Liu, L.; Yang, G.; Han, G. Why was the Indian Ocean dipole weak in the context of the extreme El Niño in 2015? J. Clim. 2017, 30, 4755-4761. [CrossRef]

50. Xie, S.P.; Annamalai, H.; Schott, F.A.; McCreary, J.P. Structure and mechanisms of South Indian Ocean climate variability. J. Clim. 2002, 15, 864-878. [CrossRef]

51. Fan, L.; Liu, Q.; Wang, C.; Guo, F. Indian Ocean dipole modes associated with different types of ENSO development. J. Clim. 2017, 30, 2233-2249. [CrossRef]

52. Webster, P.J.; Yang, S. Monsoon and ENSO: Selectively interactive systems. Q. J. R. Meteorol. Soc. 1992, 118, 877-926. [CrossRef]

53. Lau, K.M.; Yang, S. The Asian monsoon and predictability of the tropical ocean-atmosphere system. Q. J.R. Meteorol. Soc. 1996, 122, 945-957.

54. Shanas, P.R.; Aboobacker, V.M.; Albarakati, A.M.; Zubier, K.M. Climate driven variability of wind-waves in the Red Sea. Ocean Model. 2017, 119, 105-117. [CrossRef]

55. Karnauskas, K.B.; Jones, B.H. The interannual variability of sea surface temperature in the Red Sea from 35 years of satellite and in situ observations. J. Geophys. Res. Oceans 2018, 123, 5824-5841. [CrossRef]

56. Tourre, Y.M.; White, W.B. ENSO signals in global upper-ocean temperature. J. Phys. Oceanogr. 1995, 25, 1317-1332. [CrossRef]

57. Yu, L.; Rienecker, M.M. Mechanisms for the Indian Ocean warming during the 1997-98 El Nino. Geophys. Res. Lett. 1999, 26, 735-738. [CrossRef]

58. Abish, B.; Cherchi, A.; Ratna, S.B. ENSO and the recent warming of the Indian Ocean: ENSO AND THE INDIAN OCEAN WARMING. Int. J. Climatol. 2018, 38, 203-214. [CrossRef]

59. Chambers, D.P.; Tapley, B.D.; Stewart, R.H. Anomalous warming in the Indian Ocean coincident with El Nino. J. Geophys. Res. Ocean. 1999, 104, 3035-3047. [CrossRef]

60. Salim, M.; Nayak, R.K.; Swain, D.; Dadhwal, V.K. Sea surface height variability in the tropical Indian Ocean: Steric contribution. J. Indian Soc. Remote. Sens. 2012, 40, 679-688. [CrossRef]

61. Liu, Y.; Wang, L.; Zhou, W.; Chen, W. Three Eurasian teleconnection patterns: Spatial structures, temporal variability, and associated winter climate anomalies. Clim. Dyn. 2014, 42, 2817-2839. [CrossRef]

62. Cai, W.; Borlace, S.; Lengaigne, M.; Van Rensch, P.; Collins, M.; Vecchi, G.; Timmermann, A.; Santoso, A.; McPhaden, M.J.; Wu, L.; et al. Increasing frequency of extreme El Niño events due to greenhouse warming. Nat. Clim. Chang. 2014, 4, 111-116. [CrossRef]

63. Terray, P.; Dominiak, S. Indian Ocean sea surface temperature and El Niño-Southern Oscillation: A new perspective. J. Clim. 2005, 18, 1351-1368. [CrossRef] 
64. Terray, P.; Delécluse, P.; Labattu, S.; Terray, L. Sea surface temperature associations with the late Indian summer monsoon. Clim. Dyn. 2003, 21, 593-618. [CrossRef]

65. Wang, B.; An, S.I. Why the properties of El Niño changed during the late 1970s. Geophys. Res. Lett. 2001, 28, 3709-3712. [CrossRef]

66. Ding, R.; Ha, K.J.; Li, J. Interdecadal shift in the relationship between the East Asian summer monsoon and the tropical Indian Ocean. Clim. Dyn. 2010, 34, 1059-1071. [CrossRef]

67. Nakamura, N.; Kayanne, H.; Iijima, H.; McClanahan, T.R.; Behera, S.K.; Yamagata, T. Mode shift in the Indian Ocean climate under global warming stress. Geophys. Res. Lett. 2009, 36. [CrossRef]

68. Sofianos, S.S.; Johns, W.E. An oceanic general circulation model (OGCM) investigation of the Red Sea circulation: 2. Three-dimensional circulation in the Red Sea. J. Geophys. Res. Space Phys. 2003, 108. [CrossRef]

(C) 2019 by the authors. Licensee MDPI, Basel, Switzerland. This article is an open access article distributed under the terms and conditions of the Creative Commons Attribution (CC BY) license (http://creativecommons.org/licenses/by/4.0/). 